\title{
Nocardia artemisiae sp. nov., an endophytic actinobacterium isolated from a surface-sterilized stem of Artemisia annua L.
}

\author{
Guo-Zhen Zhao, ${ }^{1} \dagger$ Jie Li, ${ }^{2} \dagger$ Wen-Yong Zhu, ${ }^{1}$ Hans-Peter Klenk, ${ }^{3}$ \\ $\mathrm{Li}-\mathrm{H}$ ua $\mathrm{Xu}{ }^{1}$ and Wen-Jun $\mathrm{Li}^{1,2}$ \\ ${ }^{1}$ Key Laboratory of Microbial Diversity in Southwest China, Ministry of Education and Laboratory for \\ Conservation and Utilization of Bio-resources, Yunnan Institute of Microbiology, \\ Yunnan University, Kunming 650091, PR China
}

Correspondence

Wen-Jun Li

wjli@ynu.edu.cn or

liact@hotmail.com
${ }^{2}$ Key Laboratory of Marine Bio-resources Sustainable Utilization CAS, RNAH Center for Marine Microbiology, Guangdong Key Laboratory of Marine Materia Medica, South China Sea Institute of Oceanology, Chinese Academy of Sciences, 164 West Xingang Road, Guangzhou 510301 , PR China

${ }^{3} \mathrm{DSMZ}$ - Deutsche Sammlung von Mikroorganismen und Zellkulturen GmbH, Inhoffenstraße 7b, D-38124 Braunschweig, Germany

\begin{abstract}
A novel actinobacterium, designated $\mathrm{YIM} 65623^{\top}$, was isolated from a surface-sterilized stem of Artemisia annua L. Strain YIM 65623 ${ }^{\top}$ had morphological, biochemical, physiological and chemotaxonomic properties that were consistent with its classification in the genus Nocardia. Growth occurred with 0-7\% (w/v) NaCl (optimum 0-3\%), at pH 5.0-9.0 (optimum pH 6.0) and at $10-37{ }^{\circ} \mathrm{C}$ (optimum $20-28{ }^{\circ} \mathrm{C}$ ). Comparative 16S rRNA gene sequence analysis showed that strain YIM $65623^{\top}$ constituted a distinct sublineage within the genus Nocardia and displayed 94.1-98.2\% sequence similarity to members of established species in the genus Nocardia. However, DNA-DNA relatedness and physiological and biochemical characteristics showed that strain YIM $65623^{\top}$ could be differentiated from its closest phylogenetic relatives. The $\mathrm{G}+\mathrm{C}$ content of the genomic DNA was $69.6 \mathrm{~mol} \%$. It is proposed that strain YIM $65623^{\top}$ be classified as a representative of a novel species, Nocardia artemisiae sp. nov. The type strain is $\mathrm{YIM} 65623^{\top}$ $\left(=\right.$ DSM $45379^{\top}=$ CCTCC AA $\left.209038^{\top}\right)$.
\end{abstract}

The genus Nocardia (Trevisan, 1889) belongs to the family Nocardiaceae, a member of the suborder Corynebacterineae (Stackebrandt et al., 1997), and has undergone a revolution in its taxonomy in recent years (Kiska et al., 2002; Roth et al., 2003). Members of the genus are aerobic, Grampositive, high-G + C-content (64-72 mol\%) organisms that form extensively branched substrate mycelium and aerial hyphae that fragment into rod-shaped or coccoid non-motile elements. The genus Nocardia is also characterized by a number of chemical markers, including the presence of meso-diaminopimelic acid (DAP), arabinose, galactose and mycolic acids (Goodfellow \& Lechevalier, 1989; Goodfellow, 1992). Some novel species have been described in recent years and, at the time of writing, the

†These authors contributed equally to this work.

Abbreviation: DAP, diaminopimelic acid.

The GenBank/EMBL/DDBJ accession number for the 16S rRNA gene sequence of strain YIM 65623 ${ }^{\top}$ is GU367157.

Two supplementary figures and two supplementary tables are available with the online version of this paper. genus encompasses 80 species with validly published names. Many Nocardia species have been shown to be agents of human disease, such as Nocardia asteroides, Nocardia farcinica and Nocardia nova (Schaal \& Lee, 1992; Wallace et al., 1991), although it has also been shown that some species produce secondary metabolites of potential industrial value (Isik et al., 1999; Kinoshita et al., 2001), e.g. Nocardia uniformis and Nocardia jinanensis, which produce nocardicin and amicoumacin B, respectively. The recently described species Nocardia callitridis (Kaewkla \& Franco, 2010) and Nocardia endophytica (Xing et al., 2011) were isolated from the endophytic environment. During the course of our research on new actinobacterial resources, we obtained a novel endophytic member of the genus Nocardia, strain YIM $65623^{\mathrm{T}}$.

Strain YIM $65623^{\mathrm{T}}$ was isolated from the healthy inner tissue of a stem of Artemisia annua L., a traditional Chinese medicinal plant, which was collected in Yunnan Province, south-west China. Samples were washed thoroughly in running water to remove all soil and sonicated $(160 \mathrm{~W})$ to dislodge any soil and organic matter from the surface. After 
drying at room temperature, tissue segments were surface sterilized by immersing in $0.1 \%$ Tween 20 for $1 \mathrm{~min}$, followed by $5 \%$ (available $\mathrm{Cl}^{-}$) $\mathrm{NaClO}$ for $4 \mathrm{~min}$ (leaf) or $6 \mathrm{~min}$ (stem and root). The samples were then rinsed in $2.5 \%(\mathrm{w} / \mathrm{v}) \quad \mathrm{Na}_{2} \mathrm{~S}_{2} \mathrm{O}_{3}$ for $10 \mathrm{~min}$ to remove residual chlorine (Miché \& Balandreau, 2001; Qin et al., 2009) and washed at least three times with sterilized water. The last disinfection step was immersion in $70 \%(\mathrm{v} / \mathrm{v})$ ethanol for $4 \mathrm{~min}$ (leaf) or $6 \mathrm{~min}$ (stem and root), which was followed by a minimum of three washes with sterile water. Samples were dried on sterile filter paper in a laminar flow cabinet. To confirm that the sterilization process was successful, $0.2 \mathrm{ml}$ water from the final washing was spread onto both the isolation medium and yeast extract-malt extract agar [International Streptomyces Project (ISP) 2; Shirling \& Gottlieb, 1966] and incubated at $28{ }^{\circ} \mathrm{C}$ for $2-4$ weeks. The isolation method involved processing $1 \mathrm{~g}$ sample in a commercial blender, followed by grinding with a mortar and pestle, suspending in $9 \mathrm{ml}$ sterile water and then serially diluting $1 \mathrm{ml}$ tissue suspension to $10^{-2}$ before plating. The isolation medium was sodium propionate-asparagine-salt agar (Qin et al., 2009) supplemented with $3 \%(\mathrm{w} / \mathrm{v}) \mathrm{NaCl}$ and $\left(\mathrm{l}^{-1}\right) 25 \mathrm{mg}$ nalidixic acid and $50 \mathrm{mg}$ nystatin. A pure culture was obtained by repeated streaking on half-strength ISP 2 agar. Strain YIM $65623^{\mathrm{T}}$ was routinely cultivated on ISP 2 medium at $28{ }^{\circ} \mathrm{C}$ and stored as a glycerol suspension $(20 \%, \mathrm{v} / \mathrm{v})$ at $-80{ }^{\circ} \mathrm{C}$.

The morphological characteristics of strain YIM $65623^{\mathrm{T}}$ were assessed by light microscopy (BH-2; Olympus) and scanning electron microscopy (Philips XL30; ESEM-TMP) using 14-day-old cultures grown on ISP 2 agar. Cultural characteristics were recorded on ISP media (Shirling \& Gottlieb, 1966), Czapek's agar, potato-glucose agar and nutrient agar, prepared as described by Dong \& Cai (2001). Colours were determined using colour chips from the ISCC-NBS colour charts (standard samples, no. 2106; Kelly, 1964). Growth at 4, 10, 20, 28, 37, 40, 45, 50 and $55{ }^{\circ} \mathrm{C}$ was tested on tryptose soy agar for 21 days. Growth at $\mathrm{pH} 4-10$ (in increments of one $\mathrm{pH}$ unit) was tested using the buffer system described by Xu et al. (2005). Growth with $0,1,3,5,7,10,15$ and $20 \%$ (w/v) $\mathrm{NaCl}$ was tested at $28{ }^{\circ} \mathrm{C}$ for $14-21$ days in tryptose soy broth (TSB). Catalase, oxidase, urease and gelatinase activities, starch hydrolysis and nitrate reduction were assessed as described by Smibert \& Krieg (1994). Carbon-source utilization and other physiological and biochemical properties were analysed as described by Gordon et al. (1974).

Biomass for chemical and molecular studies was obtained by cultivation in shake flasks (about 200 r.p.m.) in TSB at $28{ }^{\circ} \mathrm{C}$ for 1 week. The isomer of diaminopimelic acid and the sugars of the whole-cell hydrolysate were determined according to the procedures described by Hasegawa et al. (1983), Lechevalier \& Lechevalier (1970) and Tang et al. (2009). Phospholipids were extracted, examined by twodimensional TLC and identified using previously described procedures (Minnikin et al., 1979; Collins \& Jones, 1980). Menaquinones were isolated according to Collins et al.
(1977) and separated by HPLC (Tamaoka et al., 1983). Mycolic acids were extracted and analysed by onedimensional TLC as described by Minnikin et al. (1980). Cellular fatty acids were extracted, methylated and analysed using the Sherlock Microbial Identification System (MIDI) according to the manufacturer's instructions. The fatty acid methyl esters were analysed using Microbial Identification software (version 4.0, TSBA40 database; MIDI). The G $+\mathrm{C}$ content of the genomic DNA was determined using the HPLC method (Mesbah et al., 1989).

Extraction of genomic DNA and PCR amplification and sequencing of the $16 \mathrm{~S}$ rRNA gene were performed as described by Li et al. (2007). Multiple alignments with sequences of the most closely related actinobacteria and calculations of sequence similarity were carried out using CLUSTAL X (Thompson et al., 1997). Phylogenetic trees were constructed using the neighbour-joining (Saitou \& Nei, 1987) and maximum-parsimony (Fitch, 1971) algorithms in MEGA version 4.0 (Tamura et al., 2007). PHYLIP version 3.6 (Felsenstein, 2002) and PHYML (Guindon \& Gascuel, 2003) were used to construct the maximum-likelihood tree (Felsenstein, 1981). The tree topologies were evaluated using the bootstrap resampling method of Felsenstein (1985) with 1000 replicates. DNA-DNA relatedness was studied according to the fluorometric microwell method (Ezaki et al., 1989; He et al., 2005).

Strain YIM $65623^{\mathrm{T}}$ was an aerobic, Gram-stain-positive organism that had morphological properties consistent with its assignment to the genus Nocardia. The welldeveloped substrate mycelium was white, brown, orange or yellowish orange, with irregular branches penetrating the agar, while the aerial hyphae were white or brown (Supplementary Table S1, available in IJSEM Online). At a late stage of growth, the hyphae fragmented into rodshaped elements with smooth surfaces (Supplementary Fig. S1). The physiological properties of strain YIM $65623^{\mathrm{T}}$ are given in the species description and differences between strain YIM $65623^{\mathrm{T}}$ and its closest phylogenetic neighbour, Nocardia mexicana DSM $44952^{\mathrm{T}}$, are shown in Table 1 . The isolate and the reference strain had different profiles for utilization and hydrolysis of some substances. Also, the temperature and $\mathrm{pH}$ for growth were different between the two strains.

Strain YIM $65623^{\mathrm{T}}$ exhibited chemotaxonomic characteristics that were consistent for the genus Nocardia. Whole-cell hydrolysates of strain YIM $65623^{\mathrm{T}}$ were rich in meso-DAP, arabinose, galactose, glucose and mannose. The polar lipid profile contained phosphatidylethanolamine, phosphatidylinositol, diphosphatidylglycerol and phosphatidylinositol mannosides. The major menaquinone was $\mathrm{MK}-8\left(\mathrm{H}_{4 \omega}\right.$ cyclo $)$, which is very similar to those described for recognized Nocardia species. In addition, TLC analysis revealed that the isolate contained mycolic acids with an $R_{\mathrm{f}}$ value of 0.47 , which was identical to that of N. mexicana DSM $44952^{\mathrm{T}}$ used as a control. The fatty acid profile contained a mixture of straight-chain saturated, unsaturated and 10-methyl 
Table 1. Different characteristics of strain YIM $65623^{\top}$ and its closest phylogenetic neighbour

All data were obtained in this study. Both strains are positive for utilization of cellobiose, dulcitol, D-fructose, D-galactose, glucose, glycerol, lactose, maltose, D-mannitol, D-mannose, L-rhamnose, sucrose, ribose and xylose and growth with $5 \%(\mathrm{w} / \mathrm{v}) \mathrm{NaCl}$, at pH 5.0-9.0 and at $10-37{ }^{\circ} \mathrm{C}$. Both strains are negative for utilization of myo-inositol. +, Positive; w, weakly positive; -, negative.

\begin{tabular}{|lcc|}
\hline Characteristic & YIM 65623 & $\begin{array}{c}\text { N. mexicana } \\
\text { DSM 44952 }\end{array}$ \\
\hline Use of sole carbon sources & & \\
$\quad$ L-Arabinose & - & + \\
Raffinose & - & + \\
Sodium acetate & - & + \\
D-Sorbitol & - & + \\
Use of L-tyrosine as a & + & - \\
sole nitrogen source & & \\
Hydrolysis of Tweens 20, 40 and 80 & - & + \\
Growth at/with: & & \\
$7 \%(\mathrm{w} / \mathrm{v}) \mathrm{NaCl}$ & $\mathrm{w}$ & - \\
$40{ }^{\circ} \mathrm{C}$ & - & + \\
$45{ }^{\circ} \mathrm{C}$ & - & $\mathrm{W}$ \\
$\mathrm{pH} 10.0$ & - & $\mathrm{w}$ \\
\hline
\end{tabular}

branched fatty acids, including $\mathrm{C}_{16: 0}(34.35 \%), 10$-methyl $\mathrm{C}_{18: 0}(16.60 \%), \mathrm{C}_{17: 1} \omega 8 c(15.92 \%), \mathrm{C}_{18: 1} \omega 9 c(12.29 \%)$, $\mathrm{C}_{16: 1} \omega 7 c$ and/or iso- $\mathrm{C}_{15: 0} 2-\mathrm{OH}(8.90 \%), \mathrm{C}_{15: 0}(4.80 \%)$, $\mathrm{C}_{18: 0}(1.81 \%), \mathrm{C}_{15: 1} \omega 6 c(1.77 \%), \mathrm{C}_{17: 0}(1.61 \%), \mathrm{C}_{14: 0}$ $(0.86 \%)$, iso- $\mathrm{C}_{16: 0}(0.38 \%)$ and anteiso- $\mathrm{C}_{17: 1} \omega 9 c(0.22 \%)$ (Supplementary Table S2). This profile most closely matches those of members of the genus Nocardia. However, strain YIM $65623^{\mathrm{T}}$ showed remarkable differences in its fatty acid profile from N. mexicana DSM $44952^{\mathrm{T}}$, such as quantitative differences in the proportions of 10-methyl $\mathrm{C}_{18: 0}, \mathrm{C}_{16: 1} \omega 07 c$ and/or iso- $\mathrm{C}_{15: 0} 2-\mathrm{OH}, \mathrm{C}_{18: 1} \omega 9 c, \mathrm{C}_{17: 1} \omega 8 c, \mathrm{C}_{15: 1} \omega 6 c$ and $\mathrm{C}_{15: 0}$. The $\mathrm{G}+\mathrm{C}$ content of the DNA of strain YIM $65623^{\mathrm{T}}$ was $69.6 \mathrm{~mol} \%$, which is in accordance with the range for the genus Nocardia.

The 16S rRNA gene sequence (1511 bp) of strain YIM $65623^{\mathrm{T}}$ was determined in this study. Phylogenetic analysis showed that strain YIM $65623^{\mathrm{T}}$ was closely related to members of the genus Nocardia. Sequence similarity calculations obtained by pairwise comparisons indicated that the closest relatives of strain YIM $65623^{\mathrm{T}}$ were Nocardia lijiangensis YIM $33378^{\mathrm{T}}$ (98.2\% $16 \mathrm{~S}$ rRNA gene sequence similarity) and $N$. mexicana OFN $785-81^{\mathrm{T}}$ $(98.1 \%)$. Lower similarities $(<98.0 \%)$ were found with the other members of the genus Nocardia. This relationship between strain YIM $65623^{\mathrm{T}}$ and other members of the genus Nocardia was also evident in the phylogenetic trees based on neighbour joining, maximum parsimony and maximum likelihood (Fig. 1 and Supplementary Fig. S2), in which strain YIM $65623^{\mathrm{T}}$ formed a distinct sublineage with $N$. mexicana OFN $785-81^{\mathrm{T}}$. To establish the precise taxonomic position of strain YIM $65623^{\mathrm{T}}$, DNA-DNA hybridization was performed between strain YIM $65623^{\mathrm{T}}$ and N. mexicana DSM $44952^{\mathrm{T}}$, which revealed $36.0 \pm 2.0 \%$ DNA-DNA relatedness, which is far below the threshold value of $70 \%$ recommended by Stackebrandt \& Goebel (1994) for assigning strains to different genomic species. DNA-DNA hybridization between strain YIM $65623^{\mathrm{T}}$ and N. lijiangensis YIM $33378^{\mathrm{T}}$ was not carried out because they were positioned in different clusters in the phylogenetic trees. Furthermore, 16S rRNA gene sequence similarities much higher than $98.1 \%$ have been found between type strains of species of the genus Nocardia that have DNADNA relatedness much lower than the $70 \%$ threshold recommended for the delineation of species (Yassin \&

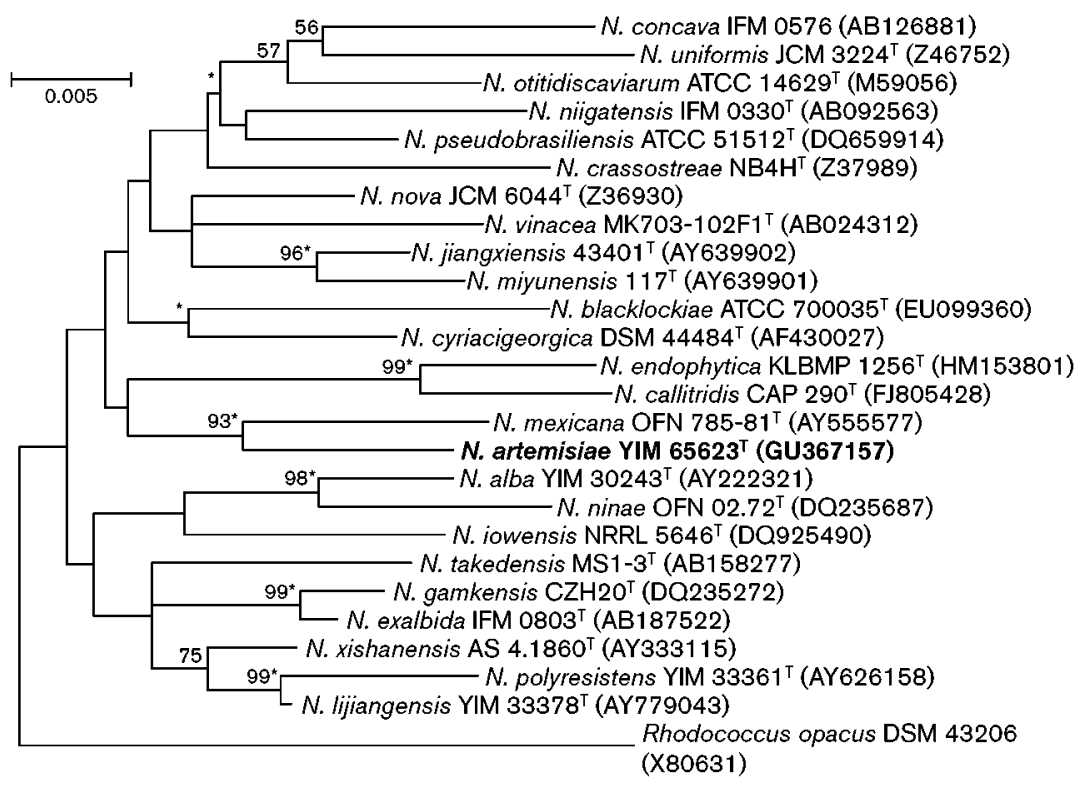

Fig. 1. Neighbour-joining phylogenetic tree based on 16S rRNA gene sequences, showing the relationships between strain YIM $65623^{\top}$ and closely related members of the genus Nocardia. Bootstrap values (>50\%) based on 1000 replicates are shown at branch nodes. Asterisks indicate that the corresponding nodes were also recovered in trees generated with the maximum-parsimony and maximum-likelihood methods. Bar, 0.005 substitutions per nucleotide position. 
Brenner, 2005; Kämpfer et al., 2007; Sun et al., 2009). Conville et al. (2000) also reported it reasonable to consider Nocardia isolates as belonging to different species if they share $\leqslant 98.5 \% 16 \mathrm{~S}$ rRNA gene sequence similarity. Strains belonging to the same species generally have at least $99.2 \%$ sequence similarity. By these criteria, strain YIM $65623^{\mathrm{T}}$ represents a novel species of the genus Nocardia.

The chemical and morphological data clearly indicate that strain YIM $65623^{\mathrm{T}}$ belongs to the genus Nocardia. However, 16S rRNA gene sequence analysis, DNA-DNA relatedness and biochemical characteristics indicated that strain YIM $65623^{\mathrm{T}}$ represents a species separate from those in the genus Nocardia with validly published names. Thus, we consider that strain YIM $65623^{\mathrm{T}}$ should be placed in a novel species, for which we propose the name Nocardia artemisiae sp. nov.

\section{Description of Nocardia artemisiae sp. nov.}

Nocardia artemisiae (ar.te.mi'si.ae. L. n. artemisia mugwort, and also a plant genus; L. gen. n. artemisiae of mugwort, of Artemisia, referring to the isolation of the type strain from Artemisia annua L.).

Aerobic, non-motile, Gram-stain-positive actinomycete that forms extensively branched substrate mycelium and aerial mycelium that bears smooth-surfaced rod-shaped spores. Good growth occurs on ISP media 2-5, Czapek's agar, potato-glucose agar and nutrient agar. Aerial mycelium is white or brown; substrate mycelium is white, brown, orange or yellowish orange on media tested. Diffusible pigments are observed on ISP 3 agar (grey-yellow) and potato-glucose agar (yellowish orange). Grows at $10-37{ }^{\circ} \mathrm{C}$ (optimum $20-$ $28{ }^{\circ} \mathrm{C}$ ), at pH 5.0-9.0 (optimum pH 6.0) and with $0-7 \%$ $\mathrm{NaCl}$ (optimum 0-3\% NaCl). Positive for catalase and urease, but negative for milk coagulation, milk peptonization, nitrate reduction, oxidase, gelatin liquefaction, hydrolysis of cellulose and starch and production of $\mathrm{H}_{2} \mathrm{~S}$. As sole carbon sources, utilizes cellobiose, dulcitol, D-fructose, Dgalactose, glucose, glycerol, lactose, maltose, D-mannitol, Dmannose, L-rhamnose, sucrose, ribose and xylose, but not L-arabinose, myo-inositol, raffinose, sodium acetate or Dsorbitol. Acid is produced from glycerol and ribose. As sole nitrogen sources, utilizes L-alanine, L-arginine, L-asparagine, glycine, L-hydroxyproline, hypoxanthine, L-lysine, L-phenylalanine, L-serine, L-tyrosine, L-valine and xanthine. Wholecell hydrolysates are rich in meso-DAP, arabinose, galactose, glucose and mannose. The phospholipids are phosphatidylethanolamine, diphosphatidylglycerol, phosphatidylinositol and phosphatidylinositol mannosides. The major menaquinone is MK- $8\left(\mathrm{H}_{4 \omega}\right.$ cyclo $)$. Mycolic acids are present. The major fatty acids are $\mathrm{C}_{16: 0}, \mathrm{C}_{18: 0} 10$-methyl, $\mathrm{C}_{17: 1} \omega 8 c$, $\mathrm{C}_{18: 1} \omega 9 c, \mathrm{C}_{16: 1} \omega 7 c$ and/or iso- $\mathrm{C}_{15: 0} 2-\mathrm{OH}$ and $\mathrm{C}_{15: 0}$. The DNA G $+\mathrm{C}$ content of the type strain is $69.6 \mathrm{~mol} \%$.

The type strain, YIM $65623^{\mathrm{T}}\left(=\mathrm{DSM} 45379^{\mathrm{T}}=\right.$ CCTCC AA $209038^{\mathrm{T}}$ ), was isolated from a surface-sterilized stem of Artemisia annua L., collected from Yunnan province, south-west China.

\section{Acknowledgements}

This research was supported by the National Basic Research Program of China (grant no. 2010CB833801) and the National Natural Science Foundation of China (grant no. U0932601).

\section{References}

Collins, M. D. \& Jones, D. (1980). Lipids in the classification and identification of coryneform bacteria containing peptidoglycans based on 2,4-diaminobutyric acid. J Appl Bacteriol 48, 459-470.

Collins, M. D., Pirouz, T., Goodfellow, M. \& Minnikin, D. E. (1977). Distribution of menaquinones in actinomycetes and corynebacteria. J Gen Microbiol 100, 221-230.

Conville, P. S., Fischer, S. H., Cartwright, C. P. \& Witebsky, F. G. (2000). Identification of nocardia species by restriction endonuclease analysis of an amplified portion of the 16S rRNA gene. J Clin Microbiol 38, 158-164.

Dong, X.-Z. \& Cai, M.-Y. (2001). Manual of Systematics and Identification of General Bacteria. Beijing: Science Press (in Chinese).

Ezaki, T., Hashimoto, Y. \& Yabuuchi, E. (1989). Fluorometric deoxyribonucleic acid-deoxyribonucleic acid hybridization in microdilution wells as an alternative to membrane filter hybridization in which radioisotopes are used to determine genetic relatedness among bacterial strains. Int J Syst Bacteriol 39, 224-229.

Felsenstein, J. (1981). Evolutionary trees from DNA sequences: a maximum likelihood approach. J Mol Evol 17, 368-376.

Felsenstein, J. (1985). Confidence limits on phylogenies: an approach using the bootstrap. Evolution 39, 783-789.

Felsenstein, J. (2002). PHYLIP (phylogeny inference package), version 3.6a. Distributed by the author. Department of Genome Sciences, University of Washington, Seattle, USA.

Fitch, W. M. (1971). Toward defining the course of evolution: minimum change for a specific tree topology. Syst Zool 20, 406-416.

Goodfellow, M. (1992). The family Nocardiaceae. In The Prokaryotes, 2nd edn, pp. 1188-1213. Edited by A. Balows, H. G. Trüper, M. Dworkin, W. Harder \& K. H. Schleifer. New York: Springer.

Goodfellow, M. \& Lechevalier, M. P. (1989). Genus Nocardia Trevisan $1889,9^{\mathrm{AL}}$. In Bergey's Manual of Systematic Bacteriology, vol. 4, pp. 2350-2361. Edited by S. T. Williams, M. E. Sharpe \& J. G. Holt. Baltimore: Williams \& Wilkins.

Gordon, R. E., Barnett, D. A., Handerhan, J. E. \& Pang, C. H.-N. (1974). Nocardia coeliaca, Nocardia autotrophica, and the nocardin strain. Int J Syst Bacteriol 24, 54-63.

Guindon, S. \& Gascuel, O. (2003). A simple, fast, and accurate algorithm to estimate large phylogenies by maximum likelihood. Syst Biol 52, 696-704.

Hasegawa, T., Takizawa, M. \& Tanida, S. (1983). A rapid analysis for chemical grouping of aerobic actinomycetes. J Gen Microbiol 29, 319322.

He, L., Li, W., Huang, Y., Wang, L. M., Liu, Z. H., Lanoot, B. J., Vancanneyt, M. \& Swings, J. (2005). Streptomyces jietaisiensis sp. nov., isolated from soil in northern China. Int J Syst Evol Microbiol 55, 1939-1944.

Isik, K., Chun, J., Hah, Y. C. \& Goodfellow, M. (1999). Nocardia uniformis nom. rev. Int J Syst Bacteriol 49, 1227-1230.

Kaewkla, O. \& Franco, C. M. M. (2010). Nocardia callitridis sp. nov., an endophytic actinobacterium isolated from a surface-sterilized root of an Australian native pine tree. Int J Syst Evol Microbiol 60, 15321536. 
Kämpfer, P., Huber, B., Buczolits, S., Thummes, K., Grün-Wollny, I. \& Busse, H.-J. (2007). Nocardia acidivorans sp. nov., isolated from soil of the island of Stromboli. Int J Syst Evol Microbiol 57, 1183-1187.

Kelly, K. L. (1964). Inter-Society Color Council - National Bureau of Standards Color Name Charts Illustrated with Centroid Colors. Washington, DC: US Government Printing Office.

Kinoshita, N., Homma, Y., Igarashi, M., Ikeno, S., Hori, M. \& Hamada, M. (2001). Nocardia vinacea sp. nov. Actinomycetologica 15, 1-5.

Kiska, D. L., Hicks, K. \& Pettit, D. J. (2002). Identification of medically relevant Nocardia species with an abbreviated battery of tests. J Clin Microbiol 40, 1346-1351.

Lechevalier, M. P. \& Lechevalier, H. A. (1970). Chemical composition as a criterion in the classification of aerobic actinomycetes. Int J Syst Bacteriol 20, 435-443.

Li, W.-J., Xu, P., Schumann, P., Zhang, Y.-O., Pukall, R., Xu, L.-H., Stackebrandt, E. \& Jiang, C.-L. (2007). Georgenia ruanii sp. nov., a novel actinobacterium isolated from forest soil in Yunnan (China), and emended description of the genus Georgenia. Int J Syst Evol Microbiol 57, 1424-1428.

Mesbah, M., Premachandran, U. \& Whitman, W. B. (1989). Precise measurement of the $\mathrm{G}+\mathrm{C}$ content of deoxyribonucleic acid by highperformance liquid chromatography. Int J Syst Bacteriol 39, 159-167.

Miché, L. \& Balandreau, J. (2001). Effects of rice seed surface sterilization with hypochlorite on inoculated Burkholderia vietnamiensis. Appl Environ Microbiol 67, 3046-3052.

Minnikin, D. E., Collins, M. D. \& Goodfellow, M. (1979). Fatty acid and polar lipid composition in the classification of Cellulomonas, Oerskovia and related taxa. J Appl Bacteriol 47, 87-95.

Minnikin, D. E., Hutchinson, I. G., Caldicott, A. B. \& Goodfellow, M. (1980). Thin layer chromatography of methanolysates of mycolic acid-containing bacteria. J Chromatogr A 188, 221-233.

Qin, S., Li, J., Chen, H. H., Zhao, G. Z., Zhu, W. Y., Jiang, C. L., Xu, L. H. $\& \mathrm{Li}$, W. J. (2009). Isolation, diversity, and antimicrobial activity of rare actinobacteria from medicinal plants of tropical rain forests in Xishuangbanna, China. Appl Environ Microbiol 75, 6176-6186.

Roth, A., Andrees, S., Kroppenstedt, R. M., Harmsen, D. \& Mauch, H. (2003). Phylogeny of the genus Nocardia based on reassessed $16 \mathrm{~S}$ rRNA gene sequences reveals underspeciation and division of strains classified as Nocardia asteroides into three established species and two unnamed taxons. J Clin Microbiol 41, 851-856.

Saitou, N. \& Nei, M. (1987). The neighbor-joining method: a new method for reconstructing phylogenetic trees. Mol Biol Evol 4, 406425.

Schaal, K. P. \& Lee, H. J. (1992). Actinomycete infections in humans - a review. Gene 115, 201-211.
Shirling, E. B. \& Gottlieb, D. (1966). Methods for characterization of Streptomyces species. Int J Syst Bacteriol 16, 313-340.

Smibert, R. M. \& Krieg, N. R. (1994). Phenotypic characterization. In Methods for General and Molecular Bacteriology, pp. 607-654. Edited by P. Gerhardt, R. G. E. Murray, W. A. Wood \& N. R. Krieg. Washington, DC: American Society for Microbiology.

Stackebrandt, E. \& Goebel, B. M. (1994). Taxonomic note: a place for DNA-DNA reassociation and $16 \mathrm{~S}$ rRNA sequence analysis in the present species definition in bacteriology. Int J Syst Bacteriol 44, 846849.

Stackebrandt, E., Rainey, F. A. \& Ward-Rainey, N. L. (1997). Proposal for a new hierarchic classification system, Actinobacteria classis nov. Int J Syst Bacteriol 47, 479-491.

Sun, W., Zhang, Y. Q., Huang, Y., Zhang, Y. Q., Yang, Z. Y. \& Liu, Z. H. (2009). Nocardia jinanensis sp. nov., an amicoumacin B-producing actinomycete. Int J Syst Evol Microbiol 59, 417-420.

Tamaoka, J., Katayama-Fujimura, Y. \& Kuraishi, H. (1983). Analysis of bacterial menaquinone mixtures by high-performance liquid chromatography. J Appl Bacteriol 54, 31-36.

Tamura, K., Dudley, J., Nei, M. \& Kumar, S. (2007). MEGA4: molecular evolutionary genetics analysis (MEGA) software version 4.0. Mol Biol Evol 24, 1596-1599.

Tang, S.-K., Wang, Y., Chen, Y., Lou, K., Cao, L.-L., Xu, L.-H. \& Li, W.-J. (2009). Zhihengliuella alba sp. nov., and emended description of the genus Zhihengliuella. Int J Syst Evol Microbiol 59, 2025-2032.

Thompson, J. D., Gibson, T. J., Plewniak, F., Jeanmougin, F. \& Higgins, D. G. (1997). The CLUSTAL_X windows interface: flexible strategies for multiple sequence alignment aided by quality analysis tools. Nucleic Acids Res 25, 4876-4882.

Trevisan, V. (1889). I Generi e le Specie delle Batteriacee. Milan: Zanaboni \& Gabuzzi (in Italian).

Wallace, R. J., Jr, Brown, B. A., Tsukamura, M., Brown, J. M. \& Onyi, G. O. (1991). Clinical and laboratory features of Nocardia nova. J Clin Microbiol 29, 2407-2411.

Xing, K., Qin, S., Fei, S.-M., Lin, Q., Bian, G.-K., Miao, Q., Wang, Y., Cao, C.-L., Tang, S.-K. \& other authors (2011). Nocardia endophytica sp. nov., an endophytic actinomycete isolated from the oil-seed plant Jatropha curcas L. Int J Syst Evol Microbiol 61, 1854-1858.

Xu, P., Li, W.-J., Tang, S.-K., Zhang, Y.-Q., Chen, G.-Z., Chen, H.-H., Xu, L.-H. \& Jiang, C.-L. (2005). Naxibacter alkalitolerans gen. nov., sp. nov., a novel member of the family 'Oxalobacteraceae' isolated from China. Int J Syst Evol Microbiol 55, 1149-1153.

Yassin, A. F. \& Brenner, S. (2005). Nocardia elegans sp. nov., a member of the Nocardia vaccinii clade isolated from sputum. Int J Syst Evol Microbiol 55, 1505-1509. 